University of Arkansas, Fayetteville

ScholarWorks@UARK

8-19-2016

\title{
You Can Often Get What You Want: Assessing the Match between Parent Preferences and Private Schools of Choice
}

\author{
Evan Rhinesmith \\ University of Arkansas, Fayetteville, etrhines@email.uark.edu \\ Patrick J. Wolf \\ University of Arkansas, Fayetteville
}

Follow this and additional works at: https://scholarworks.uark.edu/edrepub

Part of the Educational Assessment, Evaluation, and Research Commons, Educational Leadership Commons, and the Other Educational Administration and Supervision Commons

\section{Citation}

Rhinesmith, E., \& Wolf, P. J. (2016). You Can Often Get What You Want: Assessing the Match between Parent Preferences and Private Schools of Choice. Education Reform Faculty and Graduate Students Publications. Retrieved from https://scholarworks.uark.edu/edrepub/29

This Article is brought to you for free and open access by the Education Reform at ScholarWorks@UARK. It has been accepted for inclusion in Education Reform Faculty and Graduate Students Publications by an authorized administrator of ScholarWorks@UARK. For more information, please contact scholar@uark.edu. 


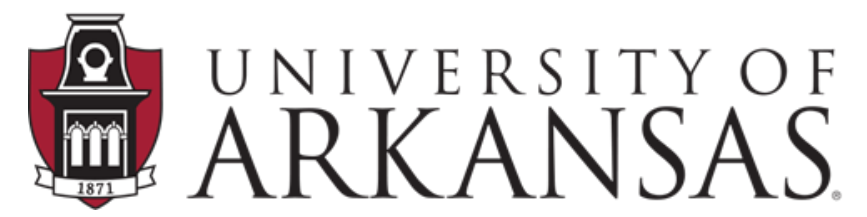

College of Education \& Health Professions Education Reform

\author{
WORKING PAPER SERIES
}

\title{
You Can Often Get What You Want: Assessing the Match between Parent Preferences and Private Schools of Choice
}

\author{
Evan Rhinesmith \\ Patrick J. Wolf, PhD
}

August 19, 2015

EDRE Working Paper 2016-11

The University of Arkansas, Department of Education Reform (EDRE) working paper series is intended to widely disseminate and make easily accessible the results of EDRE faculty and students' latest findings. The Working Papers in this series have not undergone peer review or been edited by the University of Arkansas. The working papers are widely available, to encourage discussion and input from the research community before publication in a formal, peer reviewed journal. Unless otherwise indicated, working papers can be cited without permission of the author so long as the source is clearly referred to as an EDRE working paper. 


\title{
You Can Often Get What You Want: Assessing the Match between Parent Preferences and Private Schools of Choice
}

\author{
Evan Rhinesmith (etrhines@email.uark.edu) \\ Patrick J. Wolf, PhD (pwolf@,uark.edu) \\ Department of Education Reform \\ University of Arkansas \\ 201 Graduate Education Building \\ Fayetteville, AR 72701 \\ Phone: (479) 575-3172
}

Evan Rhinesmith is a doctoral candidate and Doctoral Academy Fellow in the Department of Education Reform at the University of Arkansas. Patrick J. Wolf is Professor and $21^{\text {st }}$ Century Endowed Chair in School Choice in the Department of Education Reform at the University of Arkansas. 


\begin{abstract}
Providing parents choices in education has become an increasingly popular instrument for reforming education in the United States. While existing research on parent satisfaction in private school choice programs shows that parents are satisfied with the schools they have chosen, there is not much to explain their satisfaction. Previous research using parent surveys asks parents to rate and/or grade their school of choice, while comparing their response to their thoughts on their previous public school. This paper reports new empirical evidence that looks to offer a possible explanation for parents' satisfaction. Using data from the Milwaukee Parental Choice Program, we look to analyze whether or not parents get what they choose for when given the opportunity to choose a private school. Our analysis makes use of survey responses from parents that can be matched to students and then matched to principals. In total, there were 7,338 parents who received a survey. Of these, 3,226 parents completed a survey. In total, there were 1,868 students who responded to surveys. Parents were matched to MPCP students using a unique child ID, resulting in 1,856 parents who were matched to students. These were then matched to principals representing 123 schools participating in the MPCP. Our analysis of the MPCP examines the probability of a parent choosing a school that ranked at least above average on the specific characteristic they had listed as most important to their school choice. Since a school having a specific characteristic is a binary variable, we used Logit as the functional form of the regression equation in order to estimate the probability that parents get what they choose for.
\end{abstract}

Keywords: School choice, Parental preferences, Milwaukee, MPCP, School characteristics 


\section{INTRODUCTION}

Providing parents choices in education has become an increasingly popular instrument for reforming education in the United States. School choice programs offer parents the opportunity to enroll their children in a public or private school of their choice using public money. One argument for implementing choice in education is that it provides parents the opportunity to choose the school setting that best fits their child's needs without having to move to a different school district. Under the current education system, children are assigned to schools based on their home address. Giving parents choices in education removes the restriction on schools in which children can enroll.

At the start of the 2013-14 school year, 39 different private school choice programs existed in the United States. ${ }^{1}$ To date a majority of research on various school choice programs has focused on student achievement on standardized tests, student attainment such as graduation and college enrollment, and systemic effects of school choice programs on public schools. ${ }^{2}$

A defense of school voucher programs rests on what Amy Gutmann characterizes as, "a parental right to choose a school". ${ }^{3}$ However, existing research has questioned parents' ability to make good decisions for their child's education. ${ }^{4}$ Specifically, researchers argue that low-income parents have a stronger tendency to make ill-informed choices.

In spite of this, parents who are given the opportunity to choose a school express high levels of satisfaction with their school. This topic often receives less attention in studies of private school choice programs. Phillip Vassalo's research found that, overall, “parents are overwhelmingly more satisfied with their new schools than they were with their previous schools on a range of measures." 5

While existing research on parent satisfaction in private school choice programs shows that parents are satisfied with the schools they have chosen, there is not much to explain their satisfaction. Previous research using parent surveys asks parents to rate and/or grade their school of 
choice, while comparing their response to their thoughts on their previous public school. Other studies compare satisfaction levels between parents enrolling their children in private schools to those of parents in public schools. These studies have various shortcomings including confirmation bias, cognitive dissonance, and bias associated with the stronger educational motivations of parents who seek out school choice.

As Fuller et al argue, "Researchers are still not digging into the critical issue of why private or non-neighborhood schools at times boost parental satisfaction. ${ }^{\prime 6}$ Teske and Schneider point out that parents' high levels of satisfaction may be an "ex post" rationalization of the choices made after the effort parents must exert to choose a charter school or enroll in a private school voucher program. ${ }^{7}$ The responses of high levels of satisfaction may result from a justification of their investment. Similarly, Wolf writes, "Since parents themselves selected their child’s new school, they might feel vested in the outcome of the choice and filter their perceptions in such ways that the voucher schools look better to them even if, objectively, they are no better than the child's previous schools." 8

This paper reports new empirical evidence that looks to offer a possible explanation for parents' satisfaction. As Wolf writes, “Although it is indisputable that parents are more satisfied with their child's school if they have been given a voucher, we do not yet know why they are so much more satisfied." Using data from the Milwaukee Parental Choice Program, we look to analyze whether or not parents get what they choose for when given the opportunity to choose a private school.

In the following sections, we provide a description of the relevant literature, outline the methodology, describe the Milwaukee Parental Choice program and data, and present the initial 
findings from our analysis. The paper concludes with a discussion of results and possible future research.

\section{RELEVANT LITERATURE}

Studies of parental satisfaction in private school choice program have used a combination of random assignment and observational methodologies in order to estimate program impacts. This section reviews the findings from relevant literature on parental satisfaction to provide a foundation for our analysis.

To date, random assignment studies and quasi-experimental studies have found that parents participating in private school choice programs are often more satisfied with their schools of choice than their counterparts whose children enroll in TPS. While there are a variety of reasons for parents to choose, voucher programs appear to increase satisfaction on multiple outcomes. As Wolf says, "Voucher programs appear especially to increase parent satisfaction regarding curriculum, safety, parent-teacher relation, academics, and the religious environment of school." ${ }^{\prime 10}$ Not only do voucher programs have positive impacts on parental satisfaction, but these results are often large.

The Children's Scholarship Fund awarded 40,000 scholarships by lottery to low-income families nationwide. The lottery allowed for a randomized control trial to evaluate the impacts of the program. In 2001, Paul Peterson and David Campbell surveyed 2,300 applicants to the program, finding that parents able to enroll their child in a private school were more likely to give their school of choice an 'A' and more likely to say that they were "very satisfied" with aspects of their school compared to their public school counterparts. When Peterson and Campbell asked parents to grade their school, “72 percent of private school parents gave their child's school an A, compared to 16 percent of public school parents." ${ }^{11}$ Along with this, parents were asked to rate their satisfaction 
levels with academics, safety, discipline, and teaching values. Overall, private school parents were more likely to be very satisfied with each of the four aspects than their public school counterparts.

In a study of a private school voucher program in Charlotte, Jay Greene analyzed the impact of receiving a voucher for children grades 2 through 8 who were randomly assigned by lottery to receive a voucher to attend a private school. ${ }^{12}$ Along with the achievement measures, Greene surveyed parents to analyze opinions of private schools. After one year of participation in the program, the parents of just over 450 students (40 percent of those invited to participate) completed satisfaction surveys. Nearly twice as many parents enrolling their students in private schools assigned their school an A as their public school counterparts. As Greene writes, "Choice parents were also far more likely to report being 'very satisfied' with virtually all aspects of their children's school”. ${ }^{13}$

William Howell and Paul Peterson's 2002 book The Education Gap examines the impacts of vouchers in urban schools. They include a chapter on satisfaction in urban schools by examining randomized control trials in New York City, Dayton, the national Children's Scholarship Fund (CSF), and Washington, DC. It includes information from public schools in Dayton, Cleveland, and Edgewood school district in San Antonio. They write, "Overall, the findings are unambiguous. The effects on parents' initial satisfaction with their child's switch from a public to a private school...were large, clear, sustained and positive."14 Peterson and Howell also aggregated the responses from all of the programs to scale the responses to represent an effect size. All of the programs created an average impact of 0.92 of a standard deviation, which is very large. The program in Dayton had the largest first year effect of 1.14 standard deviations, which fell to 0.59 in year 2. In all cases, parents using a private school voucher were more satisfied than their public school counterparts. 
The Opportunity Scholarship Program in Washington, DC randomly assigned students to receive a voucher for private schools or serve in a control group. In this study, Wolf et al measured parent satisfaction in the school choice program by the percentage of parents and students who assigned a grade of either A or B to their chosen school, along with responses on a satisfaction scale. ${ }^{15}$ The results of this research showed that parents in the treatment group were " 8 percentage points more likely to give their child's school a high grade than were control group parents." 16 Interestingly, parents whose children had been enrolled in "schools in need of improvement" who received a scholarship and parents of male students were not more likely to give their school a high grade if they received a voucher. These subgroups also did not show significant achievement gains as a result of participating in the Program. It is possible that parents of these students were not satisfied because the Program did not have the desired outcome for their children. One of the issues with these differences in satisfaction is the possibility of "sour grapes" parents who were unable to leave their previous school when they did not receive a voucher.

Peterson, Howell, and Greene used a multivariate regression to analyze what exactly led to the different levels of parent satisfaction in the Cleveland Scholarship Program. ${ }^{17}$ This study used a survey of 2,020 Cleveland Scholarship and Tutoring Program applicants, 1,014 scholarship recipients and 1,006 applicants who chose not to enroll in the program. The results of their satisfaction surveys show that the "most prominent finding is that the parents with students attending established private schools were as much as 16 percentage points more satisfied than parents whose children voluntarily decided to remain in public schools."18 These results were large and statistically significant, finding that private school parents were, on average, statistically more satisfied than public school parents. 
The Georgia GOAL Scholarship Program administered surveys to parents of K-12 scholarship recipients in 2013. A total of 962 of the participants responded to the GOAL survey, 754 of whom completed the entire survey. ${ }^{19}$ Of the parents who responded, 84 percent were very satisfied with their new private school compared to their previous school, along with nearly 15 percent saying they were satisfied with their new private school. ${ }^{20}$ The parents who participated in this program were more likely to assume a large financial burden, as the GOAL scholarship does not cover the entire amount of tuition charged at Georgia private schools. While not grounded in a rigorous research design, this study suggests extremely high levels of satisfaction for parents in their choice school compared to their government assigned school.

Indiana has one of the broadest school voucher programs in the country, with nearly 4,000 families using vouchers to enroll in private schools in the program's first year. This number more than doubled in year two and had nearly 20,000 participants for the 2013-14 school year. ${ }^{21}$ Indiana policymakers were interested in knowing why parents were enrolling in choice scholarship schools. Over 4,000 Indiana parents participated in the survey, with nearly 60 percent of parents reporting dissatisfaction with their previous school and nearly 90 percent of parents saying they were "very satisfied" with their choice school. ${ }^{22}$ Again, these are important results showing the importance of parents being able to choose for their children.

While these studies all report similar findings of parent satisfaction, there is little explanation of why parents are satisfied. With that in mind, the next section describes the data and sample we use in an effort to examine whether parents get what they choose for as a possible explanation for the high levels of satisfaction.

\section{DATA}


Our analysis uses data resulting from surveys of the Milwaukee Parental Choice Program (MPCP) parents, students, and principals of participating schools from the year 2007. First piloted in 1991, the MPCP is the nation's first publicly funded urban school voucher program. Like most other school voucher and tax credit programs, the MPCP is targeted to disadvantaged families. MPCP vouchers are given to families living in Milwaukee and earning up to 300 percent of the federal poverty guideline..$^{23}$ The maximum voucher amount is $\$ 7,210$ for grades $\mathrm{K}$-8 and $\$ 7,856$ for grades 9-12. Participating families who were awarded a voucher by random lottery are able to enroll their child in a participating private school.

Our analysis makes use of survey responses from parents that can be matched to students and then matched to principals. In total, there were 7,338 parents who received a survey. Of these, 3,226 parents completed a survey. In total, there were 1,868 students who responded to surveys. Parents were matched to MPCP students using a unique child ID, resulting in 1,856 parents who were matched to students. These were then matched to principals representing 123 schools participating in the MPCP. Principal surveys provide information on school characteristics such as student-teacher ratios, facilities offered, and mission of the school.

Parent surveys provided rich data on demographics, household characteristics, and preferences on school characteristics. They also contained information on parents' rationale for choosing the school in which they enrolled their child. Table 1 offers a look at the data with characteristics of parents responding to MPCP surveys in 2007 as a whole and for the parents who were matched to students and schools.

Table 1. Characteristics of Parents in MPCP, 2007

\begin{tabular}{lcc}
\hline & Total Sample & Matched Sample \\
\hline All parents $(\mathrm{N})$ & 3,226 & 1,856 \\
\hline Ethnicity & & \\
\hline
\end{tabular}




\begin{tabular}{lrr}
\hline American Indian & $0.82 \%$ & $0.60 \%$ \\
\hline Asian & $2.31 \%$ & $2.32 \%$ \\
\hline African American & $58.64 \%$ & $54.50 \%$ \\
\hline Hispanic & $21.34 \%$ & $24.51 \%$ \\
\hline Multiple Races & $3.80 \%$ & $4.35 \%$ \\
\hline White & $13.08 \%$ & $13.72 \%$ \\
\hline Income Level & & \\
\hline$<\$ 5,000$ & $9.08 \%$ & $8.28 \%$ \\
\hline$\$ 5,001-\$ 7,500$ & $6.39 \%$ & $6.47 \%$ \\
\hline$\$ 7,501-\$ 10,000$ & $6.08 \%$ & $7.18 \%$ \\
\hline$\$ 10,001-\$ 15,000$ & $10.66 \%$ & $12.38 \%$ \\
\hline$\$ 15,001-\$ 20,000$ & $10.69 \%$ & $12.15 \%$ \\
\hline$\$ 20,001-\$ 25,000$ & $11.22 \%$ & $13.17 \%$ \\
\hline$\$ 25,001-\$ 35,000$ & $16.46 \%$ & $21.45 \%$ \\
\hline$\$ 35,001-\$ 50,000$ & $13.02 \%$ & $13.72 \%$ \\
\hline$>\$ 50,001$ & $9.24 \%$ & $5.21 \%$ \\
\hline Unknown $/$ Refused & $7.16 \%$ & $0.00 \%$ \\
\hline Education Level & & \\
\hline $8^{\text {th }}$ Grade or Below & $8.21 \%$ & $11.23 \%$ \\
\hline Some High School & $14.79 \%$ & $12.57 \%$ \\
\hline GED & $3.38 \%$ & $2.99 \%$ \\
\hline High School Graduate & $27.62 \%$ & $24.93 \%$ \\
\hline Some College & $28.27 \%$ & $30.24 \%$ \\
\hline Technical Degree & $3.44 \%$ & $3.97 \%$ \\
\hline 4-year College Degree & $9.33 \%$ & $11.08 \%$ \\
\hline Post-Graduate Work & $3.13 \%$ & $2.99 \%$ \\
\hline Student Grade Level & & \\
\hline Elementary & $37.54 \%$ & $28.80 \%$ \\
\hline Middle & $35.28 \%$ & $30.32 \%$ \\
\hline High & $1.18 \%$ & \\
\hline
\end{tabular}

Comparing the two columns, we note that the total sample size shrinks when matching parents to students and participating schools. The demographics are relatively similar, with matched parents being slightly less likely to be African American and slightly more likely to have attended college. Parents in the matched sample were more likely to have children in high school grades and less likely to have children in elementary school. While the total number of matched parents, students, and principals results in a total of 1,856 observations, these numbers varied with each of the different school characteristics of interest, which will be discussed later in this paper. 


\section{RESEARCH DESIGN}

In this analysis we rely on information gathered from parent surveys that were then matched against the information gathered about the schools their children were attending. The 2007 parent surveys asked parents to rate the importance of thirteen different school characteristics. Parents were then

asked to list which of the qualities was the most important. The seven characteristics we matched to principal surveys were:

- Academic Quality

- Class Size

- School Facilities

- Racial Diversity

- Religious Instruction

- Teacher Quality

- School Location

In the parent survey, responses to the "most important characteristic" were coded as binary variables.

School information was provided through principal surveys and Wisconsin Department of Public Instruction. Some school-supplied data were reported as real continuous numbers, which were then recoded as binary dependent variables so that we could use Logit estimation consistently throughout the analysis.

Class size is measured using the average class size of MPCP schools as provided by the Wisconsin Department of Public Instruction administrative data. A school is classified as having small class sizes if their average class size is smaller than or equal to the overall average of MPCP class size, 11.49 students per teacher.

Racial Diversity is measured using the average percent minority student enrollment in MPCP schools. MPCP schools that were at or above the average percentage of minority students enrolled 
were coded as "racially diverse". Total enrollment and minority enrollments were gathered from the Wisconsin Department of Public Instruction.

School facilities consisted of a school lunch program, computer lab, library, gymnasium, and a cafeteria. The average number of facilities in an MPCP school was 4 . If a school had 4 or more facilities, they were coded with a 1 on facilities. Otherwise they were coded 0 on facilities

In the principal survey, school leaders had to select from four options of which mission statements most accurately reflected their school's mission. These were:

- Our school exists to provide the children of parish members with a thorough training in the Scripture, the doctrines of the church, and in preparation for the sacraments.

- Our school exists to nurture believers in the faith and as a means of evangelizing nonbelievers.

- Our school exists to teach God's Word to as many people as possible.

- Our school exists to provide a high-quality academic education in the context of a safe, nurturing environment.

Schools selecting one of the first three mission statements were classified as schools with a religious focus.

In the case of school location, we made use of parents listing school location as a "very important quality" when choosing their school and used parents' self-reported travel time as the dependent variable. Parents had six options for travel time: 10 minutes or less, 11-20 minutes, 21-30 minutes, 46 minutes to 1 hour, and more than hour. Longer travel times were coded with higher values on travel time. Analysis of school location made use of an ordered logit estimation.

While there is typically an inherent endogeneity problem with parents selecting academic quality as their most important school characteristic, since high school-level performance on tests could lead parents of students at the school to decide that academic quality is especially important, our analysis is not susceptible this problem. Academic achievement on standardized tests for MPCP 
schools was not publicly available until after these surveys were administered. In this case, we create our Academic Quality variable using test scores from the year 2012. This results in an imperfect measure of academic quality in 2007, but it avoids the issue of endogeneity. Academic quality is measured using the percentage of students at the school scoring proficient and above on the state test in both reading and mathematics. Math and reading scores were each used as their own “Academic Quality” dependent variable. An “Overall Academic Quality” variable consisted of the average of each school's reading and math scores. Schools that were one standard deviation above the mean score for MPCP schools were classified as "high quality" academic institutions.

Our analysis of the MPCP examines the probability of a parent choosing a school that ranked at least above average on the specific characteristic they had listed as most important to their school choice. Since a school having a specific characteristic is a binary variable, we used Logit as the functional form of the regression equation in order to estimate the probability that parents get what they choose for. Our Logit estimations result from the following equation:

$$
\operatorname{Pr}\left(y_{j}\right)=\beta_{0}+\beta_{1} Z_{i}+\beta_{2} X_{i}+\varepsilon
$$

where $y_{j}$ indicates whether school $j$ offered the specific characteristic, $Z_{i}$ is a binary variable representing a parent listing the characteristics as the most important when choosing a school, and $\mathrm{X}_{i}$ is a vector of covariates assembled from baseline surveys. Items in $\mathrm{X}_{i}$ include survey respondent's education level, poverty status indicated by household income, an indicator variable for race, current grade level of the student, number of school age children in the family, an indicator variable for twoparent households, and an indicator variable for parent's employment status.

In the case of racial subgroup analyses, we used interaction terms to test whether African American and Hispanic parents stating a preferred school characteristic "got what they chose for" when compared to parents of the same race who did not state a preference and when compared to 
parents of all races stating a preference. Both school characteristic and parents race are binary variables, allowing us to continue to use Logit as the functional form of the regression to compare parents of similar and different races. Our Logit estimations of racial subgroups result from the following equation:

$$
\operatorname{Pr}\left(y_{j}\right)=\beta_{0}+\beta_{1} Z_{i}+\beta_{2} Z_{i}^{*} K_{i}+\beta 3 X_{i}+\varepsilon
$$

where $y_{j}$ indicates whether school $j$ offered the specific characteristic, $Z_{i}$ is a binary variable representing a parent listing the characteristics as the most important when choosing a school and $\mathrm{X}_{i}$ is a vector of covariates assembled from baseline surveys. $Z_{i}{ }^{*} K_{i}$ is the interaction term, allowing us to estimate the probability of a parent of a specific race enrolling their child in a school that offers the specific characteristic they deemed most important when making their choice. Items in $\mathrm{X}_{i}$ include survey respondent's education level, poverty status indicated by household income, an indicator variable for race, current grade level of the student, number of school age children in the family, an indicator variable for two-parent households, and an indicator variable for parent's employment status.

\section{ANALYSIS \& RESULTS}

In this section, we present the results of our evaluation of parents getting the school quality for which they chose, using the empirical methods outlined earlier. The objective of our research is to see if parents choosing schools enroll their child in a school that offers the most important characteristic. All of the models include parent's demographic characteristics: race, education level, income, child's grade level, number of school age children, two-parent households, and employment status.

The analysis used a set of 7 separate estimations of the "getting what you choose for" dependent variable. The academic quality estimate is broken down into three separate analyses, reading quality, math quality, and overall quality. Each analysis had its own unique outcome variable 
that was coded 1 for parents who listed that as the most important characteristic and 0 if the parent did not list that as the most important characteristic. The dependent variables are coded as 1 if the school is at least above average on that characteristic and 0 if the school is not above average on that characteristic, with the lone exception being school location, which uses parents self-reported travel time to get to school as a proxy for the convenience of their chosen school's location.

The results of the analyses are mixed but tilt somewhat towards making a case for the idea that parents who have the opportunity to choose do get that quality from their selected school, depending on the quality that is most important to them. In the models estimating academic quality and religious instruction, stating that those qualities were the most important when making a choice in schools resulted in an increased likelihood of parents getting what they chose for. This was also the case for school location. In the case of religious instruction and academic quality measured by math scores, the result was significant at the $99 \%$ confidence level. The result was significant at the $95 \%$ confidence level for overall academic quality and school location, and was marginally significant—at the $90 \%$ confidence level—for academic quality as measured by reading scores. Parents listing facilities as their most important quality yielded a marginally significant result, but in the opposite of the hypothesized direction. Parents listing facilities as their most important characteristic were $33.74 \%$ less likely to enroll their child in a school with above average facilities compared with parents who did not list facilities as the most important school factor. This results was not robust to minor changes in the operational definition of "above average facilities", however, and therefore could be a chance or spurious finding. There were no significant differences in the likelihood of parents getting what they chose for if class size, racial diversity, or teacher quality was their most important school characteristic. We consider each of these school characteristics in turn. Academic Quality 
Table 2 presents the estimation results for parents listing academic quality as the most important characteristic when choosing their school. For overall academic quality, the estimate is positive and significant at the $95 \%$ confidence level. This shows that parents who listed academic quality as the most important quality were $5.47 \%$ more likely (as measured by first differences) to enroll their child in a school that provided high quality academics as measured by test scores.

Table 2a represents academic quality as measured by reading scores. In this case, the results were marginally significant, showing that parents selecting academic quality as the most important characteristic were $4.77 \%$ more likely to enroll their child in a school that provided high academic quality as measured by the percentage of students scoring proficient and above on reading standardized tests.

Table $2 \mathrm{~b}$ shows the estimate results for academic quality as measured by math standardized tests. The result is significant at the $99 \%$ confidence level, showing that parents listing academic quality as the most important quality were $7.58 \%$ more likely to select a school providing high quality math performance than parents who did not list academic quality as the most important characteristic when selecting a school. 
Table 2. Parents Stating Quality of Education as Most Important Quality, Overall Scores

Logit Estimates of Overall Academic Quality

Overall Academic Quality

Parent's Education Level

Household Income $(\$ 1,000$ s)

Multiple Races

American Indian

Asian

African American

Hispanic

Student grade Level

Number of School-age Children

Two-Parent Household

Parent Employed

Observations

Model chi-square

Pseudo R-squared

Log likelihood
$0.276^{* *}$

$(0.137)$

0.013

$(0.035)$

$-0.005$

$(0.006)$

$-0.221$

$(0.374)$

$-0.846$

$(1.085)$

$-1.042$

(0.655)

0.191

(0.200)

$-0.880^{* * *}$

$(0.259)$

$-0.117^{* * *}$

(0.037)

$0.115^{* *}$

(0.047)

0.031

(0.166)

$-0.042$

(0.158)

1,230

57.17

0.0418

$-654.7$

Standard errors in parentheses

*** $\mathrm{p}<0.01,{ }^{* *} \mathrm{p}<0.05,{ }^{*} \mathrm{p}<0.1$ 
Table 2a. Parents Stating Quality of Education as Most Important Quality, Reading Scores

Logit Estimates of Academic Quality (Reading)

Academic Quality

$0.230 *$

Parent's Education Level

$(0.136)$

0.027

$(0.035)$

Household Income $(\$ 1,000$ s)

$-0.003$

Multiple Races

$(0.006)$

$-0.229$

$(0.374)$

American Indian

$-0.849$

Asian/Pacific Islander

$-1.011$

$(0.655)$

African American

0.248

$(0.200)$

Hispanic

$-0.837 * * *$

$(0.259)$

Student Grade Level

$-0.120 * * *$

$(0.037)$

Number of School Age Children

$0.110 * *$

$(0.047)$

Two Parent Household

Parent Employed

$-0.067$

$(0.157)$

Observations

1,230

Model chi-square

60.80

Pseudo R-squared

0.0439

Log likelihood

$-661.8$

Standard errors in parentheses

*** $\mathrm{p}<0.01,{ }^{*} * \mathrm{p}<0.05, * \mathrm{p}<0.1$ 
Table 2b. Parents Stating Quality of Education as Most Important Quality, Math Scores

Logit Estimates of Academic Quality (Math)

\begin{tabular}{|c|c|}
\hline Academic Quality & $\begin{array}{l}0.346^{* * *} \\
(0.133)\end{array}$ \\
\hline Parent's Education Level & $\begin{array}{l}-0.006 \\
(0.034)\end{array}$ \\
\hline Household Income $(\$ 1,000 \mathrm{~s})$ & $\begin{array}{l}-0.003 \\
(0.006)\end{array}$ \\
\hline Multiple Races & $\begin{array}{c}0.039 \\
(0.355)\end{array}$ \\
\hline American Indian & $\begin{array}{l}-0.886 \\
(1.085)\end{array}$ \\
\hline Asian/Pacific Islander & $\begin{array}{c}-1.146^{*} \\
(0.656)\end{array}$ \\
\hline African American & $\begin{array}{c}0.270 \\
(0.198)\end{array}$ \\
\hline Hispanic & $\begin{array}{l}-0.595^{* *} \\
(0.243)\end{array}$ \\
\hline Student Grade Level & $\begin{array}{l}-0.155^{* * *} \\
(0.036)\end{array}$ \\
\hline Number of School Age Children & $\begin{array}{l}0.112^{* *} \\
(0.046)\end{array}$ \\
\hline Two Parent Household & $\begin{array}{c}0.063 \\
(0.160)\end{array}$ \\
\hline Parent Employed & $\begin{array}{l}-0.034 \\
(0.152)\end{array}$ \\
\hline Observations & 1,230 \\
\hline Model chi-square & 56.63 \\
\hline Pseudo R-squared & 0.0393 \\
\hline Log likelihood & -692.9 \\
\hline
\end{tabular}

Standard errors in parentheses

*** $\mathrm{p}<0.01,{ }^{* *} \mathrm{p}<0.05,{ }^{*} \mathrm{p}<0.1$

\section{Class Size}

Results for estimates of parents who stated that small class sizes were the most important characteristic when choosing a school for their child are shown in Table 3. These show no significant results concerning securing smaller class size when that is what parents choose for. 
Table 3. Parents Stating Small Class Size as Most Important Quality

\section{Logit Estimates of Class Size}

$\begin{array}{lc}\text { Small Class Size } & 0.389 \\ \text { Parent's Education Level } & (0.542) \\ & 0.110^{* * *} \\ \text { Household Income }(\$ 1,000 \mathrm{~s}) & (0.040) \\ & 0.015^{* *} \\ \text { Multiple Races } & (0.007) \\ & -0.963^{* *} \\ \text { American Indian } & (0.408) \\ & 0.229 \\ \text { Asian/Pacific Islander } & (0.768) \\ & 0.246 \\ \text { African American } & (0.493) \\ \text { Hispanic } & -0.950^{* * *} \\ & (0.205) \\ \text { Student Grade Level } & -1.760^{* * *} \\ \text { Number of School Age Children } & (0.300) \\ \text { Two Parent Household } & -0.111^{* *} \\ \text { Parent Employed } & (0.044) \\ & -0.053 \\ & (0.057) \\ & 0.041 \\ & (0.194) \\ & -0.240 \\ & (0.189)\end{array}$

$\begin{array}{ll}\text { Observations } & 1,230\end{array}$

Model chi-square $\quad 86.47$

Pseudo R-squared $\quad 0.0799$

Log likelihood $\quad-497.9$

Standard errors in parentheses

$* * * \mathrm{p}<0.01,{ }^{* *} \mathrm{p}<0.05,{ }^{*} \mathrm{p}<0.1$

\section{Facilities}

Table 4 shows results for the estimated probability of having enrolled their child in a school with more extensive facilities if parents who listed facilities as the most important characteristic when choosing a school getting that quality. These results were marginally significant and negative, showing that parents who listed 
facilities as the most important quality were less likely to get that quality from their school than parents who did not list facilities as their most important quality.

Table 4. Parents Stating School Facilities as Most Important Quality

Logit Estimates of School Facilities

\begin{tabular}{|c|c|}
\hline School Facilities & $\begin{array}{c}-1.465^{*} \\
(0.814)\end{array}$ \\
\hline Parent's Education Level & $\begin{array}{l}-0.024 \\
(0.033)\end{array}$ \\
\hline Household Income $(\$ 1,000 \mathrm{~s})$ & $\begin{array}{c}0.003 \\
(0.005)\end{array}$ \\
\hline Multiple Races & $\begin{array}{c}0.187 \\
(0.333)\end{array}$ \\
\hline American Indian & $\begin{array}{c}0.214 \\
(0.798)\end{array}$ \\
\hline Asian/Pacific Islander & $\begin{array}{l}-0.991 * * \\
(0.503)\end{array}$ \\
\hline African American & $\begin{array}{c}0.156 \\
(0.185)\end{array}$ \\
\hline Hispanic & $\begin{array}{l}1.145^{* * *} \\
(0.236)\end{array}$ \\
\hline Student Grade Level & $\begin{array}{l}0.183^{* * *} \\
(0.035)\end{array}$ \\
\hline Number of School Age Children & $\begin{array}{l}-0.182^{* * *} \\
(0.045)\end{array}$ \\
\hline Two Parent Household & $\begin{array}{c}0.151 \\
(0.156)\end{array}$ \\
\hline Parent Employed & $\begin{array}{c}0.024 \\
(0.148)\end{array}$ \\
\hline Observations & 1,230 \\
\hline Model chi-square & 106.3 \\
\hline Pseudo R-squared & 0.0689 \\
\hline Log likelihood & -718.9 \\
\hline
\end{tabular}

Standard errors in parentheses
$* * * \mathrm{p}<0.01,{ }^{* *} \mathrm{p}<0.05, * \mathrm{p}<0.1$

Racial Diversity

Table 5 shows estimates of the probability of parents enrolling their students in racially diverse schools when listing racial diversity as the most important characteristic when choosing a school. 
These results show that there is no significant difference between parents listing racial diversity as the most important characteristic and parents who did not getting what they chose for.

Table 5. Parents Stating Racial Diversity as Most Important Quality

$$
\text { Logit Estimates of Racial Diversity }
$$

$\begin{array}{lc}\text { Racial Diversity } & 0.013 \\ \text { Parent's Education Level } & (0.692) \\ & -0.163^{* * *} \\ \text { Household Income }(\$ 1,000 \mathrm{~s}) & (0.035) \\ & -0.012^{* *} \\ \text { Multiple Races } & (0.006) \\ & 1.545^{* * *} \\ \text { American Indian } & (0.348) \\ & 1.705^{*} \\ \text { Asian/Pacific Islander } & (0.871) \\ & 0.928^{*} \\ \text { African American } & (0.478) \\ \text { Hispanic } & 2.002^{* * *} \\ & (0.196) \\ \text { Student Grade Level } & 1.953^{* * *} \\ & (0.236) \\ \text { Number of School Age Children } & -0.053 \\ \text { Two Parent Household } & (0.039) \\ \text { Parent Employed } & -0.022 \\ & (0.050) \\ & -0.041 \\ & (0.170) \\ & -0.132 \\ & (0.170)\end{array}$

Observations $\quad 1,230$

Model chi-square $\quad 183.6$

Pseudo R-squared $\quad 0.130$

Log likelihood $\quad-613.3$

$$
\begin{aligned}
& \text { Standard errors in parentheses } \\
& { }_{* * *} \mathrm{p}<0.01,{ }^{* *} \mathrm{p}<0.05,{ }^{*} \mathrm{p}<0.1
\end{aligned}
$$

\section{Religious Instruction}

Table 6 presents the results for the estimated probability of having enrolled their child in a school with a religious focus for parents who expressed religious education as the most important school 
characteristic when choosing their specific school. The coefficient on the religious instruction variable is significant at the $99 \%$ confidence level. Using first differencing methods shows that parents who listed religious instruction as the most important characteristic when selecting their school were $16.42 \%$ more likely to enroll their child in a school that included religious instruction in their school's mission.

Table 6. Parents Stating Religious Instruction as Most Important Quality

Logit Estimates of Religious Instruction

Religious Instruction

Parent's Education Level

Household Income $(\$ 1,000$ s)

Multiple Races

American Indian

Asian/Pacific Islander

African American

Hispanic

Student Grade Level

Number of School Age Children

Two Parent Household

Parent Employed

Observations

Model chi-square

Pseudo R-squared

Log likelihood
$0.680 * * *$

$(0.222)$

$-0.009$

(0.034)

$0.010^{*}$

(0.006)

$-0.379$

(0.346)

$-0.479$

(0.900)

$-0.498$

$(0.553)$

$-0.576^{* * *}$

(0.198)

0.218

$(0.232)$

0.009

$(0.037)$

$-0.154 * * *$

(0.051)

$-0.263$

(0.169)

$-0.477 * * *$

(0.158)

979

54.38

0.0426

$-611.7$

Standard errors in parentheses

${ }^{* * *} \mathrm{p}<0.01,{ }^{* *} \mathrm{p}<0.05,{ }^{*} \mathrm{p}<0.1$ 


\section{Teacher Quality}

Table 7 lists the estimation results for parents listing high quality teachers as the most important characteristic when selecting a school for their child. Estimates yielded no statistically significant difference in the rate of having enrolled their child in a school classified as high in teacher quality between parents listing this as the most important characteristic and those who did not.

Table 7. Parents Stating Quality of Teachers as Most Important Quality

Logit estimates of Teacher Quality

Teacher Quality

Parent's Education Level

$0.065^{* *}$

$(0.030)$

Household Income $(\$ 1,000 \mathrm{~s})$

0.003

(0.005)

Multiple Races

$-1.166^{* * *}$

$(0.326)$

American Indian

$-0.900$

$(0.737)$

Asian/Pacific Islander

$-1.964 * * *$

$(0.543)$

African American

$-1.597 * * *$

$(0.193)$

Hispanic

$-0.980 * * *$

$(0.215)$

Student Grade Level

$0.138^{* * *}$

$(0.033)$

Number of School Age Children

$-0.068$

(0.044)

Two Parent Household

$-0.094$

$(0.147)$

Parent Employed

0.027

(0.139)

Observations

Model chi-square

Pseudo R-squared

0.0615

Log likelihood

$-786.6$

Standard errors in parentheses

${ }^{* * *} \mathrm{p}<0.01,{ }^{* *} \mathrm{p}<0.05,{ }^{*} \mathrm{p}<0.1$ 


\section{School Location}

Table 8 shows the estimation results for parents stating that school being conveniently located in relation to their home was a very important quality. In order to estimate this result, we made use of an ordered logit estimation. This estimate yielded a result that is significant at the 95\% confidence level and is negative. This shows that parents who listed school location of their child's chosen school as a very important quality were more likely to travel ten minutes or less to get to school. In this case, $6.54 \%$ more likely to enroll their child in a school that was within 10 minutes of their home. As parents had to travel farther from home to get their child to school, the less likely they were to list school location as a very important school quality. Graph 1 below shows the differences in parents selecting school location based on convenience of travel time. As the graph shows, the longer parents had to travel to school, the less likely they were to select a school's location as being important in their decision.

Table 8. Parents Stating Location of School as a Very Important Quality

Ordered Logit Estimates of School Location

School Location

Parent's Education Level

Household Income (\$1,000s)

Multiple Races

American Indian

Asian/Pacific Islander

African American

Hispanic

Student Grade Level
$-0.275 * *$

$(0.110)$

$-0.009$

$(0.027)$

$-0.014 * * *$

$(0.005)$

$0.910^{* * *}$

(0.304)

$1.644 * *$

(0.683)

$1.904 * * *$

$1.216^{* * *}$

$(0.175)$

$0.390^{*}$

(0.203)

$0.330^{* * *}$

(0.031) 
Number of School Age Children $\quad 0.052$

(0.038)

Two Parent Household $\quad-0.250^{*}$

$(0.131)$

Parent Employed

$-0.328^{* * *}$

$(0.124)$

Observations

1,227

Model chi-square

Pseudo R-squared

Log likelihood

Standard errors in parentheses

$* * * \mathrm{p}<0.01,{ }^{* *} \mathrm{p}<0.05, * \mathrm{p}<0.1$

Graph 1. Predicted Probabilities of Parents Selecting School Location

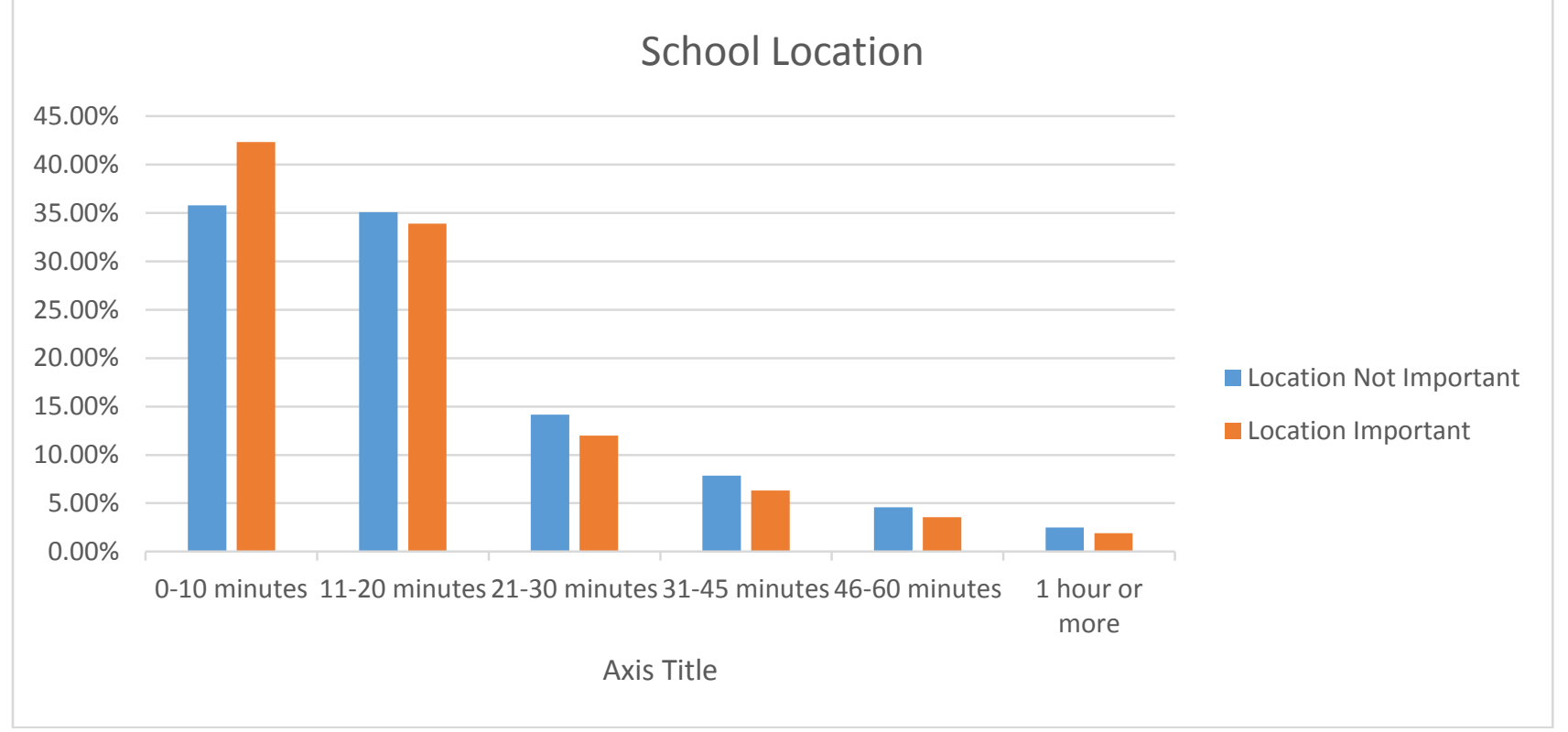

As the results show, parents stating religious instruction as their most important characteristic for a chosen school were $16.42 \%$ more likely to get that from the school they chose than parents who did not list this as the most important quality. This was a similar result for 
academic quality, as the parents choosing schools after listing this as their most important characteristic were nearly $9 \%$ more likely to get high quality in math and nearly $7 \%$ more likely in terms of overall academic quality compared to parents who did not list this as their most important school quality. Parents selecting for academic quality were $5.5 \%$ more likely to get this when measured by reading. However, this latter result is marginally significant.

\section{Results by Racial Subgroups}

In this section, we present the results of our evaluation of minority parents getting the school characteristic for which they chose, using similar methods as before. All of the models include parent demographic characteristics: race, education level, income, child's current grade, number of school age children, two parent household, and employment status. However, in this case, we are interested in the results for Hispanic and African American Parents, who are the most highly represented minority populations in our sample.

These analyses look at the same 7 estimations of the "getting what you choose for" dependent variables and compare parents to those of the of the same race who did not list the school characteristic of interest as the most important characteristic. We also compare the within race differences to differences among parents of all other races on the same characteristic of interest. The academic quality estimate is, once again, broken down into three separate analyses: reading quality, math quality, and overall quality. Location estimates are broken down by parents listing location as very important and self-reported travel times to get to school.

\section{Academic Quality}

Table 9 presents estimation results for African American and Hispanic parents listing academic quality as the most important characteristic when choosing their school. In this case, the results for Hispanic parents were not statistically significant. However, the interaction term for African American parents is negative and significant at the $99 \%$ confidence level. The results show that 
African American parents stating academic quality as the most important characteristic are $5.7 \%$ less likely (as measured using marginal effects) to enroll their child in a school offering high academic quality as measured by standardized test scores compared with African American parents not stating educational quality as the most important characteristic. Non-African American parents stating academic quality as the most important characteristic were $17.6 \%$ more likely to enroll their child in a school with high quality academics. Therefore, we can conclude that African American parents stating educational quality as the most important quality were even less likely to select a school offering that quality than non-African American parents stating educational quality as the most important characteristic.

Table 9 a represents academic quality measured by math scores. In the case of our subgroup analyses, the results for African American parents were significant at the $95 \%$ confidence level and negative, showing that African American parents selecting academic quality as the most important characteristic when measured by math scores were $8.6 \%$ less likely to enroll their child in a school that provided this characteristic than African American parents who did not state academic quality as their most important characteristic. Similar to the overall academic quality measure, non-African American parents were $18.4 \%$ more likely to enroll their child in a school with high academic quality measured by math standardized test scores, showing African American parents seeking schools with high academic quality were less likely than non-African American counterparts.

Table $9 \mathrm{~b}$ shows estimates of academic quality as measured by reading scores. The results are similar to the previous estimates of academic quality for African American parents and were significant at the $99 \%$ confidence level. These results show African American parents preferring to enroll their child in a school with high quality academics measured by reading scores were $8.3 \%$ less likely to enroll their child in a school offering high quality academics than African American parents 
who did not state academic quality as the most important quality. They were also less likely compared to their non-African American counterparts, who were $17.7 \%$ more likely to get what they chose for compared to non-African American parents who did not state academic quality was the most important characteristic when choosing their school.

Table 9. Minority Parents Stating Quality of Education as Most Important Quality, Overall Scores Logit Estimates of Overall Academic Quality, Subgroup Analysis African American Hispanic

Academic Quality

$1.161 * * *$

0.177

African American

$(0.413)$

$1.721 * * *$

African American*Acad. Quality

(0.461)

$-1.241 * * *$

$(0.476)$

Parent's Education Level

0.040

$(0.033)$

0.014

$-0.006$

$(0.035)$

Household Income ( $\$ 1,000$ s)

(0.006)

$-0.007$

Student Grade Level

$-0.112^{* * *}$

$(0.037)$

(0.006)

Number of School Age Children

$0.123^{* * *}$

$-0.110^{* * *}$

$(0.047)$

(0.037)

$-0.016$

$0.102^{* *}$

Two Parent Household

$(0.165)$

$(0.046)$

$-0.053$

Employment Status

$(0.157)$

$-0.044$

$(0.160)$

$-0.022$

(0.156)

Hispanic

$-1.762^{* * *}$

(0.637)

0.944

Hispanic*Acad. Quality

Observations

1,229

1,229

Model chi-square

50.96

50.71

Pseudo R-squared

0.0373

0.0371

Log likelihood

$-657.6$

$-657.7$

Standard errors in parentheses

*** $\mathrm{p}<0.01,{ }^{* *} \mathrm{p}<0.05,{ }^{*} \mathrm{p}<0.1$ 
Table 9a. Minority Parents Stating Quality of Education as Most Important Quality, Math Quality Logit Estimates of Academic Quality, Math, Subgroup Analysis African American

Hispanic

Academic Quality

$0.872^{* *}$

0.081

African American

(0.343)

$1.435^{* * *}$

(0.208)

African American*Acad. Quality

$(0.399)$

$-0.991 * *$

$(0.414)$

Parent's Education Level

0.015

$-0.003$

$(0.032)$

$(0.033)$

Household Income (\$1,000s)

$-0.004$

$-0.005$

Student Grade Level

(0.006)

(0.006)

$-0.150 * * *$

$-0.147 * * *$

(0.036)

$0.112^{* *}$

(0.036)

Number of School Age Children

(0.046)

$0.095^{* *}$

Two Parent Household

0.022

$(0.045)$

$(0.158)$

$-0.047$

$-0.027$

Employment Status

$(0.150)$

$(0.154)$

$-0.020$

Hispanic

$(0.150)$

$-1.472^{* * *}$

$(0.520)$

Hispanic*Acad. Quality

0.883

$(0.539)$

Observations

1,229

1,229

Model chi-square

48.83

45.32

Pseudo R-squared

0.0339

0.0314

Log likelihood

$-696.5$

$-698.3$

Standard errors in parentheses

*** $\mathrm{p}<0.01,{ }^{* *} \mathrm{p}<0.05,{ }^{*} \mathrm{p}<0.1$ 
Table 9b. Minority Parents Stating Quality of Education as Most Important Quality, Reading Quality Logit Estimates of Academic Quality, Reading, Subgroup Analysis African American Hispanic

\begin{tabular}{|c|c|c|}
\hline Academic Quality & $\begin{array}{c}1.140^{* * *} \\
(0.413)\end{array}$ & $\begin{array}{c}0.125 \\
(0.211)\end{array}$ \\
\hline African American & $\begin{array}{c}1.788^{* * *} * \\
(0.459)\end{array}$ & \\
\hline African American*Acad. Quality & $\begin{array}{c}-1.272^{* * *} \\
(0.474)\end{array}$ & \\
\hline Parent's Education Level & $\begin{array}{r}0.052 \\
(0.033)\end{array}$ & $\begin{array}{c}0.028 \\
(0.034)\end{array}$ \\
\hline Household Income $(\$ 1,000$ s) & $\begin{array}{l}-0.004 \\
(0.006)\end{array}$ & $\begin{array}{l}-0.005 \\
(0.006)\end{array}$ \\
\hline Student Grade Level & $\begin{array}{c}-0.116 * * * \\
(0.037)\end{array}$ & $\begin{array}{c}-0.113 * * * \\
(0.037)\end{array}$ \\
\hline Number of School Age Children & $\begin{array}{c}0.118^{* *} \\
(0.047)\end{array}$ & $\begin{array}{c}0.096^{* *} \\
(0.046)\end{array}$ \\
\hline Two Parent Household & $\begin{array}{l}-0.042 \\
(0.164)\end{array}$ & $\begin{array}{l}-0.086 \\
(0.159)\end{array}$ \\
\hline Employment Status & $\begin{array}{l}-0.075 \\
(0.156)\end{array}$ & $\begin{array}{l}-0.043 \\
(0.155)\end{array}$ \\
\hline Hispanic & & $\begin{array}{c}-1.790 * * * \\
(0.635)\end{array}$ \\
\hline Hispanic*Acad. Quality & & $\begin{array}{c}0.979 \\
(0.657)\end{array}$ \\
\hline $\begin{array}{l}\text { Observations } \\
\text { Model chi-square } \\
\text { Pseudo R-squared } \\
\text { Log likelihood }\end{array}$ & $\begin{array}{c}1,229 \\
56.59 \\
0.0409 \\
-663.6\end{array}$ & $\begin{array}{c}1,229 \\
53.78 \\
0.0389 \\
-665\end{array}$ \\
\hline \multicolumn{3}{|c|}{$\begin{array}{l}\text { Standard errors in parentheses } \\
* * * \mathrm{p}<0.01,{ }^{* *} \mathrm{p}<0.05, * \mathrm{p}<0.1\end{array}$} \\
\hline
\end{tabular}


Hispanic parents who did not deem small class sizes as the most important characteristic. NonHispanic parents stating small class as an important characteristic were $0.9 \%$ less likely to enroll their child in a school with small class sizes than all other parents listing small class sizes as the most important characteristic when choosing a school. Thus, the likelihood of an Hispanic parent choosing a school that provided them with the small class sizes they wanted were more likely to select a school with that characteristic than their non-Hispanic counterparts.

Table 10. Minority Parents Stating Small Class Size as Most Important Quality

\section{Logit Estimates of Small Class Size, Subgroup Analysis}

African American

Hispanic

Class Size

$-0.040$

$(0.231)$

African American

$-0.479 *$

(0.271)

African American*Class Size

0.241

$(0.330)$

Parent's Education Level

$0.168^{* * *}$

$(0.037)$

Household Income $(\$ 1,000$ s)

$0.014 * *$

$-0.029$

(0.173)

Student Grade Level

(0.007)

$-0.114 * * *$

$(0.043)$

$-0.009$

$(0.056)$

$-0.105$

(0.189)

$-0.234$

(0.184)

$0.093 * *$

$(0.040)$

$0.015^{* *}$

(0.007)

$-0.121 * * *$

(0.043)

$-0.037$

(0.056)

Two Parent Household

0.266

Employment Status

(0.183)

$-0.274$

(0.185)

Hispanic

Hispanic*Size

Observations

1,230

1,230

Model chi-square

41.66

63.69

Pseudo R-squared

0.0385

0.0589

Log likelihood

$-520.3$

$-509.3$

Standard errors in parentheses

*** $\mathrm{p}<0.01,{ }^{* *} \mathrm{p}<0.05,{ }^{*} \mathrm{p}<0.1$ 


\section{Facilities}

Table 11 presents results for the subgroup analyses of parents stating facilities as the most important school characteristic when choosing a school. As we can see, the results are not statistically significant for both African American and Hispanic parents.

Table 11. Minority Parents Stating Facilities as Most Important Quality

\begin{tabular}{lcc}
\hline \multicolumn{1}{c}{ Logit Estimates of School Facilities, Subgroup Analysis } & \\
& African American & Hispanic \\
\hline & & -0.105 \\
School Facilities & -0.164 & $(0.200)$ \\
African American & $(0.270)$ & \\
African American*Facilities & -0.319 & \\
& $(0.340)$ & \\
Parent's Education Level & 0.059 & -0.016 \\
& $(0.358)$ & $(0.032)$ \\
Household Income $(\$ 1,000 s)$ & $-0.070 * *$ & 0.003 \\
& $(0.030)$ & $(0.005)$ \\
Student Grade Level & 0.003 & $0.183 * * *$ \\
& $(0.005)$ & $(0.035)$ \\
Number of School Age Children & $0.179 * * *$ & $-0.195^{* * *}$ \\
& $(0.035)$ & $(0.044)$ \\
Two Parent Household & $-0.220 * * *$ & 0.062 \\
Employment Status & $(0.044)$ & $(0.150)$ \\
& 0.219 & 0.020 \\
Hispanic & $(0.152)$ & $(0.147)$ \\
Hispanic*Facilities & 0.031 & $1.139 * * *$ \\
Pseudo R-squared & $(0.145)$ & $(0.440)$ \\
Log likelihood & & -0.060
\end{tabular}




\section{Racial Diversity}

Table 12 presents results for minority parents stating racial diversity as the most important quality

when choosing a school. The result for African American parents is negative but not statistically

significant. The results for Hispanic parents is positive but not statistically significant.

Table 12. Minority Parents Stating Racial Diversity as Most Important Quality

\section{Logit Estimates of Racial Diversity, Subgroup Analysis}

African American

Hispanic

Racial Diversity

$\begin{array}{cc}0.081 & -0.307 \\ (1.168) & (0.245)\end{array}$

African American

$1.022^{* * *}$

African American* Racial Diversity

(1.425)

Parent's Education Level

$-0.221 * * *$

(0.032)

Household Income $(\$ 1,000$ s)

$-0.011^{* *}$

(0.006)

$-0.044$

Student Grade Level

$(0.037)$

$-0.051$

(0.048)

0.106

(0.161)

$-0.130$

(0.162)

$-0.136 * * *$

$(0.034)$

$-0.013^{* *}$

$(0.006)$

$-0.025$

$(0.037)$

$-0.014$

$(0.047)$

Two Parent Household

$-0.404 * * *$

Employment Status

$(0.156)$

$-0.056$

Hispanic

$(0.159)$

$0.614^{* * *}$

$(0.209)$

Hispanic* Racial Diversity

Observations

1,230

103.7

1,228

Model chi-square

0.0735

71.49

Pseudo R-squared

0.0509

Log likelihood

$-653.2$

$-666.6$

Standard errors in parentheses

*** $\mathrm{p}<0.01,{ }^{* *} \mathrm{p}<0.05,{ }^{*} \mathrm{p}<0.1$ 


\section{Religious Instruction}

Table 13 shows estimates for African American and Hispanic parents stating religious instruction as the most important school quality when choosing. Neither the result for African American nor Hispanic parents stating religious instruction as the most important quality when choosing a school were statistically different from 0 .

Table 13. Minority Parents Stating Religious Instruction as Most Important Quality

\section{Logit Estimates of Religious Instruction, Subgroup Analysis} African American

Hispanic

\begin{tabular}{|c|c|c|}
\hline Religious Instruction & $\begin{array}{l}-0.069 \\
(0.209)\end{array}$ & $\begin{array}{l}0.274^{*} \\
(0.163)\end{array}$ \\
\hline African American & $\begin{array}{c}-0.899 * * * \\
(0.241)\end{array}$ & \\
\hline African American*Religious Instruction & $\begin{array}{c}0.468 \\
(0.288)\end{array}$ & \\
\hline Parent's Education Level & $\begin{array}{l}-0.018 \\
(0.032)\end{array}$ & $\begin{array}{l}-0.002 \\
(0.034)\end{array}$ \\
\hline Household Income $(\$ 1,000 \mathrm{~s})$ & $\begin{array}{l}0.010^{*} \\
(0.006)\end{array}$ & $\begin{array}{l}0.010^{*} \\
(0.006)\end{array}$ \\
\hline Student Grade Level & $\begin{array}{c}0.015 \\
(0.037)\end{array}$ & $\begin{array}{c}0.012 \\
(0.037)\end{array}$ \\
\hline Number of School Age Children & $\begin{array}{c}-0.165^{* * *} \\
(0.050)\end{array}$ & $\begin{array}{c}-0.143 * * * \\
(0.051)\end{array}$ \\
\hline Two Parent Household & $\begin{array}{l}-0.213 \\
(0.166)\end{array}$ & $\begin{array}{l}-0.165 \\
(0.163)\end{array}$ \\
\hline Employment Status & $\begin{array}{c}-0.449 * * * \\
(0.156)\end{array}$ & $\begin{array}{c}-0.470^{* * * *} \\
(0.156)\end{array}$ \\
\hline Hispanic & & $\begin{array}{c}0.894^{* * *} \\
(0.290)\end{array}$ \\
\hline Hispanic*Religious Instruction & & $\begin{array}{l}-0.379 \\
(0.343)\end{array}$ \\
\hline Observations & 977 & 977 \\
\hline Model chi-square & 43.45 & 38.41 \\
\hline Pseudo R-squared & 0.0341 & 0.0301 \\
\hline Log likelihood & -615.7 & -618.2 \\
\hline
\end{tabular}




\section{Teacher Quality}

Table 14 lists estimates for minority parents listing high quality teachers as the most important school characteristic when selecting their child's school. These estimates yielded no statistically significant difference in the rate of enrolling children in a school classified as having high quality teachers compared to parents who did not list this as the most important quality.

Table 14. Minority Parents Stating Teacher Quality as Most Important Quality

\section{Logit Estimates of Teacher Quality, Subgroup Analysis} African American

Hispanic

$\begin{array}{lc}\text { Teacher Quality } & -0.074 \\ & (0.218) \\ \text { African American } & -0.950^{* * *} \\ & (0.285) \\ \text { African American*Teacher Quality } & 0.033 \\ & (0.304) \\ \text { Parent's Education Level } & 0.094^{* * *} \\ & (0.028) \\ \text { Household Income }(\$ 1,000 s) & 0.003 \\ & (0.005) \\ \text { Student Grade Level } & 0.133^{* * *} \\ & (0.033) \\ \text { Number of School Age Children } & -0.072 * \\ & (0.043) \\ \text { Two Parent Household } & -0.146 \\ \text { Employment Status } & (0.143) \\ & 0.021 \\ & (0.137)\end{array}$

Hispanic

$.950^{* * *}$

0.033

$(0.304)$

$0.059 * *$

$(0.029)$

0.005

$(0.005)$

$0.116 * * *$

(0.032)

$-0.073^{*}$

$(0.042)$

0.143

$-0.014$

$(0.134)$

0.347

$(0.323)$

Hispanic*Teacher Quality

Observations

$1,230 \quad 1,230$

Model chi-square

$69.88 \quad 24.50$

Pseudo R-squared

0.0417

0.0146

Log likelihood

$-803.2$

$-825.9$

$$
\begin{aligned}
& \text { Standard errors in parentheses } \\
& * * * \mathrm{p}<0.01,{ }^{* *} \mathrm{p}<0.05,{ }^{*} \mathrm{p}<0.1
\end{aligned}
$$

\section{School Location}

The estimation results for minority parents stating that school being conveniently located in relation 
to their home was a very important quality, we find no statistically significant results. In order to estimate this result, we made use of an ordered logit estimation. While insignificant, these results follow a similar pattern as our whole group estimation, with parents being less willing to travel longer distances for a school.

Table 15. Minority Parents Stating Teacher Quality as Most Important Quality

\section{Ordered Logit Estimates of School Location, Subgroup Analysis} African American

\begin{tabular}{lcc} 
& African American & Hispanic \\
\hline School Location & -0.189 & $-0.250^{* *}$ \\
& $(0.170)$ & $(0.123)$ \\
African American & $0.872^{* * *}$ & \\
African American*School Location & $(0.155)$ & \\
& -0.113 & -0.008 \\
Parent's Education Level & $(0.220)$ & $(0.027)$ \\
& -0.011 & $-0.014^{* * *}$ \\
Household Income (\$1,000s) & $(0.026)$ & $(0.005)$ \\
& $-0.014^{* * *}$ & $0.326^{* * *}$ \\
Student Grade Level & $(0.005)$ & $(0.030)$ \\
& $0.324 * * *$ & $0.063^{*}$ \\
Number of School Age Children & $(0.031)$ & $(0.038)$ \\
Two Parent Household & $0.070^{*}$ & $-0.389^{* * *}$ \\
& $(0.038)$ & $(0.126)$ \\
Employment Status & $-0.237 *$ & $-0.289^{* *}$ \\
Hispanic & $(0.129)$ & $(0.123)$ \\
Hispanic*School Location & $-0.323^{* * *}$ & $-0.642^{* * *}$ \\
& $(0.123)$ & $(0.198)$ \\
Observations & & 0.205 \\
Model chi-square & & $(0.258)$ \\
Lseudo R-squared & & 1,227 \\
\hline
\end{tabular}

Standard errors in parentheses $* * * \mathrm{p}<0.01, * * \mathrm{p}<0.05, * \mathrm{p}<0.1$

Analyses for minority parents getting what they chose for were not statistically significant for most estimates. Results for African American parents were negative for academic quality and positive for Hispanic parents selecting schools based on class size. Hispanic parents stating small 
class size as their most important characteristic for a chosen school were $6 \%$ more likely to get that from the school they chose than parents who did not list this as the most important quality. Results for academic quality were less encouraging, as African American parents choosing schools after listing this as their most important characteristic were nearly $6 \%$ less likely to get high quality academics overall, $8 \%$ less likely in terms of academic quality measured by reading scores compared to parents who did not list this as their most important school quality. These results were highly significant at the $99 \%$ confidence level. Parents selecting for academic quality were nearly 9\% less likely to get this when measured by math. This result was significant at the $95 \%$ confidence level.

\section{CONCLUSION}

As the results show, parents stating religious instruction as their most important characteristic for a chosen school were $14 \%$ more likely to get that from the school they chose than parents who did not list this as the most important quality. There was a similar result for academic quality, as the parents choosing schools after listing this as their most important characteristic were nearly 9\% more likely to get high quality in math and nearly $7 \%$ more likely in terms of overall academic quality compared to parents who did not list this as their most important school quality. Parents selecting for academic quality were 5.5\% more likely to get this when measured by reading. However, this latter result is only marginally significant. The results for minority parents-specifically African American parents_-are more bleak, showing that African American parents stating academic quality as the most important characteristic when choosing a school were less likely to enroll their child in a school offering high quality academics as measured by standardized test scores.

Parents who said that school location was very important in their decision were $6.5 \%$ more likely to choose a school that was within ten minutes of their home. Also, as parents had to travel longer, they were less likely to list school location as a very important quality. Parents who said that small class sizes, racial diversity, or teacher quality were the most important school characteristics 
were not significantly more likely to enroll their child in a school ranked above average on those characteristics, controlling for family background factors, than parents who did not list those factors as most important. These results held true for subgroup analyses, yielding no statistically significant results on any measure, except in the case of class size for Hispanic parents. These estimates yielded a marginally significant result, showing Hispanic parents were $6.2 \%$ more likely to enroll their child in a school with small class sizes than Hispanic parents who did not list small class size as the most important characteristic.

Finally, the analysis of parental preferences for extensive school facilities yielded a perverse finding, showing that those who choose a school based on facilities are less likely to get one. That association was only marginally statistically significant and was highly sensitive to how the "extensive facilities" variable was coded. Estimates on minority parents choosing facilities did not yield a statistically significant result.

What might explain this pattern of mixed results regarding whether or not parents get what they choose for? First, the varying ability of parents to identify differences across schools might itself vary based on the specific school characteristic in question. It might be much clearer to a parent that some schools do or do not have a religious focus or especially strong academics (even if they don't advertise their school-level test scores) but it might be much more difficult for them to distinguish relatively low class sizes from relatively high ones.

Second, parents might be choosing from within choice sets limited by school location or school religious affiliation and thus enrolling their child in a school that is relatively high on the characteristic that is most important for them within their choice set. If the schools in their limited choice set all are relatively low on that factor, such as racial diversity or school facilities, but a parent 
is effectively optimizing their choice within constraints, that still would show up in the analysis as a parent not getting what they chose for.

Third, the explanatory power of our control variables might be providing an especially tough test for our "get what you choose for" analyses, and only the religious focus and academic quality associations are sufficiently strong to survive that test. For example, student race has a powerful influence on whether or not a student enrolls in a school with a high level of racial diversity. If a student's race also influenced whether or not a parent listed "racial diversity" as their most important school characteristic, the more fundamental race variable might be claiming co-variance with the dependent variable that otherwise would be explained by preference for racial diversity. Also, while parents may state that racial diversity is an important characteristic when choosing a school, individual parents may have a different definition of diversity. Thus, a better way to interpret the effects of preferring a certain school characteristic on a parent's ability to get what they choose for is that our analysis indicates the predictive power of specific preferences on student enrollments in a school that meets those preferences controlling for several powerful background factors that may be jointly influencing both preferences and choices.

This study also does not identify how parents make their choices. There is the possibility that parents who are given the opportunity to choose are motivated to actively seek out information about schools. It is also possible that schools of choice advertise their schools to potential choosers. Further research is necessary to understand how parents make choices. This specific study can be further improved by including the "location" of the school quality when considering whether or not parents get what they choose for in school choice programs, perhaps as a mechanism to estimate parent "win sets" and provide a more localized estimate of whether or not they get what they choose for. 
These analyses from a school voucher program offer a small contribution to our understanding of parent decision making when choices are offered to those who did not have the resources to make choices before. These results indicate that parents are able to make choices in schools that match their stated preferences when give the opportunity to choose a school, at least when those preferences center on a religious focus or academic quality. This is an important result that could help to explain why parents are seemingly so satisfied when given the opportunity to enroll in private schools. Still, critics of school choice might look at the same pattern of results and instead conclude that parents are ineffective choosers of schools, since for the remaining four school factors (class size, school diversity, teacher quality, and facilities) the association between wanting them and actually getting them was not statistically significant or even perverse. We suspect that the mixed nature of our results is largely a function of limitations in our research design and measures limitations that are endemic to these types of school analyses. Still, the fact that we have difficulty studying rigorously the essential question of whether or not parents get what they choose for should not excuse us for at least making the attempt. It is better to know a little about something important, with limitations and qualifications, than to know nothing at all.

\footnotetext{
${ }^{1}$ Alliance for School Choice, Hope, Action, Results: Yearbook 2013-14, 2014, pp. 1-110, http://allianceforschoolchoice.org/wp-content/uploads/2014/01/AFC_2013-14_Yearbook.pdf?58ca27

${ }^{2}$ See for example, Forster, G. A Win-Win Solution: The Empirical Evidence on School Choice. Indianapolis, IN: Friedman Foundation for Educational Choice, April 2013; Egalite, A. J. "Measuring Competitive Effects From School Voucher Programs: A Systematic Review," Journal of School Choice, 7:4, pp. 443-464.

${ }^{3}$ Gutmann, A. "Assessing Arguments for School Choice: Pluralism, Parental Rights, or Educational Results?" In Alan Wolfe, editor, School Choice: The Moral Debate, Princeton, NJ: Princeton University Press, 2003, pp. 126148.

${ }^{4}$ See for example, Gilles, S. G. "Why Parents Should Choose," in Paul E. Peterson and Bryan C. Hassel, editors, Learning from School Choice, Washington, DC: Brookings, 1998, pp. 395-407.; Gutmann "Assessing Arguments for School Choice", Buckley \& Schneider "What Do Parents Want From Schools? Evidence From the Internet" ${ }^{5}$ Vassallo, P. (2000) "More Than Grades: How Choice Boosts Parental Involvement and Benefits Children". Policy Analysis, No. 383.

${ }^{6}$ Fuller, B., Elmore, R., \& Orfield, G. (1996). "Policy-making in the Dark: Illuminating the School Choice Debate". In B. Fuller, R. Elmore, \& G. Orfield (Eds.), Who Chooses? Who Loses? Culture, Institutions, and the Unequal Effects of School Choice. New York: Teachers College Press.

${ }^{7}$ Teske, P. \& Schneider, M. (2001). "What Research Can Tell Policymakers About School Choice". Journal of Policy Analysis and Management, Vol. 20, No. 4, 609-631.
} 
${ }^{8}$ Wolf, P. J. (2008). "School Voucher Programs: What the Research Says About Parental School Choice". Brigham Young University Law Review, 2008:2, pp. 415-446.

${ }^{9}$ Wolf, P. J. (2008). "School Voucher Programs: What the Research Says About Parental School Choice". Brigham Young University Law Review, 2008:2, pp. 415-446.

${ }^{10}$ Wolf, P. J. (2008). "School Voucher Programs: What the Research Says About Parental School Choice". Brigham Young University Law Review, 2008:2, pp. 415-446.

${ }^{11}$ Peterson, P. E. \& Campbell, D. E. (2001). “An Evaluation of the Children's Scholarship Fund”. Program on Education Policy and Governance, Harvard.

${ }^{12}$ Greene, J. P. (2001). "Vouchers in Charlotte: Vouchers and the test-score gap". Education Next, 1(2), 55-60.

${ }^{13}$ Greene, J. P. (2001). "Vouchers in Charlotte: Vouchers and the test-score gap". Education Next, 1(2), 55-60.

${ }^{14}$ Howell, W. G., \& Peterson, P. E. (2002). The Education Gap: Vouchers and Urban Schools. Washington, DC: Brookings Institution Press.

${ }^{15}$ Wolf, P. J., Gutmann, B., Puma, M., Kisida, B., Rizzo, L., Eissa, N., \& Carr, M. (2010). Evaluation of the DC Opportunity Scholarship Program: Final Report, U.S. Department of Education, Institute of Education Sciences, National Center for Education Evaluation and Regional Assistance, Washington, DC: U.S. Government Printing Office, NCEE 2010-4018.

${ }^{16}$ Wolf, P. J., Gutmann, B., Puma, M., Kisida, B., Rizzo, L., Eissa, N., \& Carr, M. (2010). Evaluation of the DC Opportunity Scholarship Program: Final Report, U.S. Department of Education, Institute of Education Sciences, National Center for Education Evaluation and Regional Assistance, Washington, DC: U.S. Government Printing Office, NCEE 2010-4018.

${ }^{17}$ Greene, J. P., Howell, W. G., \& Peterson, P. E. (1999). "Lessons from the Cleveland Scholarship Program”. In P. Peterson \& B. Hassel (eds.) Learning from School Choice. Washington, DC: Brookings Institute.

${ }^{18}$ Greene, J. P., Howell, W. G., \& Peterson, P. E. (1999). "Lessons from the Cleveland Scholarship Program". In P. Peterson \& B. Hassel (eds.) Learning from School Choice. Washington, DC: Brookings Institute.

${ }^{19}$ Kelly, J. P. \& Scafidi, B. (2013). More Than Scores: An Analysis of Why and How Parents Choose Private Schools. www.edchoice.org/CMSModules/EdChoice/FileLibrary/1031/More-Than-Scores.pdf.

${ }^{20}$ Kelly, J. P. \& Scafidi, B. (2013). More Than Scores: An Analysis of Why and How Parents Choose Private Schools. www.edchoice.org/CMSModules/EdChoice/FileLibrary/1031/More-Than-Scores.pdf.

${ }^{21}$ DiPerna, P. (2014). Why Indiana Voucher Parents Choose Private Schools. http://www.edchoice.org/Research/Reports/Why-Indiana-Voucher-Parents-Choose-Private-Schools.aspx ${ }^{22}$ DiPerna, P. (2014). Why Indiana Voucher Parents Choose Private Schools. http://www.edchoice.org/Research/Reports/Why-Indiana-Voucher-Parents-Choose-Private-Schools.aspx ${ }^{23}$ www.edchoice.org 